\title{
CD11c Positive
}

National Cancer Institute

\section{Source}

National Cancer Institute. CD11c Positive. NCI Thesaurus. Code C133812.

An indication that CD11c expression has been detected in a sample. 